\title{
Islamic-Based Concept Mathematics Teaching Material for the Students of Elementary School Teacher Education Department
}

\author{
Nuhyal Ulia ${ }^{1}$, Imam Kusmaryono ${ }^{2}$, Mohamad Hariyono ${ }^{3}$ \\ Universitas Islam Sultan Agung, Semarang Indonsesia ${ }^{1,2}$ \\ Universitas Terbuka, Semarang Indonesia ${ }^{3}$ \\ \{nuhyalulia@unissula.ac.id ${ }^{1}$, kusmaryono@unissula.ac.id², mohamad.hariyono@ecampus.ut.ac.id ${ }^{3}$ \}
}

\begin{abstract}
The base concept of mathematics is one of the subject courses of elementary school teacher education. Internalization of islamic values must also be carried out in the delivery of this course to achieve the vision and mission of islamic academic culture. The purpose of this research is to determine the stage of development of teaching material, to knowing validation test and practical test of teaching material. The research subjects were students of elementary school teacher education department in Universitas Islam Sultan Agung. The research method used is research and development esearch design. The development phase used includes a preliminary study, development and validation. The results of the validation obtained an average score of 3.87 included in good criteria. While the practicality test results obtained an average score of 4.36 on the criteria very well in limited trials, and in the large-scale trials obtained an average of 4.51 on very good criteria.
\end{abstract}

Keywords: base concept of mathematics, teaching materials, internalization of islamic values, the students of elementary school teacher education department.

\section{Introduction}

From the various visions and missions of Islamic universities in Indonesia, it can be seen that the planting of Islamic values is the goal. Like "Bismillah, building a generation of khairu Ummah" is the vision of Universitas Islam Sultan Agung (UNISSULA) which is familiar to the academic community of UNISSULA. To realize this vision, UNISSULA's mission is to organize Islamic higher education in the framework of Islamic preaching which is qualityoriented and universal equality by reconstructing and developing science and technology (IPTEK) based on Islamic values. Based on the vision and mission, lectures at UNISSULA and other Islamic universities run with the internalization of Islamic values in them. Likewise with lectures in the PGSD FKIP UNISSULA study program. One of the courses in the PGSD study program is the basic concept of elementary mathematics.

In elementary mathematics basic concepts courses, students learn basic mathematical concepts such as mathematical logic, the concept of numbers, algebraic concepts which include linear equations and inequalities and other materials that form the basis of courses in mathematics. Even though for PGSD students, the material presented is not only basic but the 
core material to support mathematics in elementary schools. As is well known, at the elementary school level the concept becomes very important. Do not let elementary school students have a concept that is not strong because the teacher's delivery regarding concept material is still lacking. States that the ultimate goal of learning mathematics is so that the concept of learning mathematics in schools can be used by students in everyday life, learning mathematics in primary schools has a very big role [1] so that planning and learning for prospective elementary school teachers becomes the foundation for making it happen.

Learning carried out at Unissula applies BudaI (Islamic Academic Culture), one of which is to carry out lectures with the integration of Islamic values. This also applies to elementary mathematics basic concepts courses. However, the existing teaching materials do not meet the BudaI value. The existing teaching materials only convey general material related to lectures. Has not included the internalization of Islamic values in it. Even though teaching materials are important in learning, like drinking without a glass, teaching materials are the main means of learning. In addition, teaching materials are materials, information, tools / media used by lecturers to carry out learning to create an atmosphere that spurs students to learn [2].

Teaching materials also function as (a) guidelines for teachers who will direct all activities in the learning process, as well as the substance of competencies that should be taught to students, (b) guidelines for students who will direct all their activities in the learning process, as well as a substance of potential should be learned or mastered, (c) means of evaluating the achievement or mastery of learning outcomes [3]. In addition, the benefits obtained from the preparation of teaching materials include a) the teacher has teaching materials that can help in carrying out learning, b) learning activities become more interesting, c) students have many opportunities to learn independently with the guidance of educators, and d) students find it easy to learn every competency that must be mastered. Teaching materials have an important role in the curriculum that must be prepared so that the implementation of learning can achieve the expected goals. The teaching materials for basic elementary mathematics concepts, which were previously general in nature, only lead to a discussion of material and have not been presented with the internalization of Islamic values as presented in the relevant verse of the Qur'an and explained their relationship and application. Therefore, it takes teaching materials that contain the internationalization of Islamic values. In elementary mathematics basic concepts course, students are expected to be able to apply them. In lectures, teaching materials have a function that is not much different from learning teaching materials in schools. It's just that the target in lectures is students. Once the importance of teaching materials, it is necessary to develop teaching materials that contain the internalization of Islamic values in order to realize the vision and mission of building a generation of khoiru ummah.

Islam as the religion of Rahmatal lil Alamin is guided by the Al Quran and hadith as the source of all knowledge. So all knowledge is in the Koran, therefore it is not a difficult thing when it comes to internalizing Islamic values in the course material. In the subject of basic mathematical concepts, initially we will consider general mathematics, how can there be an internalization of Islamic values? Even though there are many things that can be related between mathematics and Islam. As an example in the Al quran surah al ikhlas verse 1 أللَّهُ أَحَدُ Which means Say: "He is Allah, the One and Only".

There it is clear that the number 1 is the original number in mathematics and is also contained in the Al Quran. Mathematics and Islam are two things that are mutually integrated. In Islamic teachings, it contains a lot of the concept of numbers. Therefore, it is very logical if mathematics learning is associated with Islamic values. One of the applications of the affective domain in mathematics is through the internalization of values to students including 
the values of faith and goodness through the strategy of internalizing Islamic values [4]. The internalization of Islamic values in mathematics is not new. Previously, the study of internalization of Islamic values in mathematics learning was carried out by Abdussakir [5] by introducing the concept of integration of mathematics and Islam. Other research related to the internalization of Islamic values was conducted by Kohar [6], Krniati [7], La Jaama[8] and Nihayati [9].

Internalization of Islamic values in mathematics can be carried out in several strategies. Among them with an analogy strategy. One example is the number system material. In the set of integers, writing the set of integers $Z=\{\ldots,-3,-2,-1,0,1,2,3, \ldots\}$ in certain religions has been analogous to the journey of human life from birth. Starting from the left to the right. The analogy is that when humans are born they are already in negativity because they have borne the sins of Adam and Eve. This analogy clearly contradicts the teachings of Islam, because Islam states that every human being is born in a state of nature, which is pure from $\sin$. If writing a set of integers is analogous to the journey of human life, then writing $Z=\{0,1,-1,2$, $-2,3,-3, \ldots\}$ or $Z=\{0,+1,+2,+3, \ldots\}$ Can be used as an analogy in Islam. This is based on the hadith of the Prophet Muhammad SAW which was narrated from Abu Hurairah r.a that "Every child is born in a state of fitrah, then both parents make him a Jew, Christian, or Magi." According to this analogy, then every birth starts from 0 and then depends on the education received whether it will be positive or negative.

From the above background, it is very much needed to develop teaching materials for basic concepts of elementary mathematics based on the internalization of Islamic values. It is hoped that the developed teaching materials can present mathematical concepts with Islamic integration from both the Qur'an and the hadiths. And finally learning with Islamic academic culture can be implemented properly as a strategy in realizing the vision and mission. On the basis of the description above, the main problems in this research which are formulated are: 1) What is the stage of developing teaching materials for basic concepts of elementary mathematics based on the internalization of Islamic values? 2) Does the teaching material for the basic concepts of elementary mathematics based on the internalization of Islamic values that are developed meet the valid and practical criteria?

\section{Method}

The research method used is the Research and Development (R \& D) model, namely by producing a product in the form of teaching materials for elementary mathematics basic concepts courses based on the internalization of Islamic values. The stages in this study are based on the opinion of Samsudi [10] including 1) the preliminary study stage. At this stage, field studies are carried out related to the teaching materials used in elementary mathematics basic concepts lectures and literature studies as a follow-up to field studies because they will find solutions found from the results of field studies. Field studies carried out in elementary mathematics basic concepts lectures were carried out by interviewing both students and lecturers. Information obtained from field studies was used as material for literature studies by looking for references and related research results. And from the literature study, it is hoped that a solution will be obtained to solve the problem. 2) The development stage, from the results of preliminary studies, namely field studies and literature studies, are used as the basis for developing teaching materials for basic concepts of elementary mathematics based on the internalization of Islamic values. At this stage of development it becomes the core process of development research, so that researchers should try their best so that the products developed 
can work well. At this development stage there is a validation process. After the product is developed, the validity of the teaching material is tested at this stage. The validity test is given to the expert by filling in the expert validation sheet that has been designed.

The validation results are evaluated and revised according to the suggestions given. This stage can be repeated if the product being developed requires repeated revisions. The validation process ends when the validator has declared the product suitable for use. After the expert validation test, a limited scale trial was carried out. Limited scale trials were conducted only on 4 students participating in elementary mathematics basic concepts lectures. 3) Validation stage, at this stage a wide-scale trial was carried out on all students participating in the elementary mathematics basic concepts course. The results of a limited-scale trial are evaluated first. Inputs and improvements were made before the large scale trial was carried out. After the three development stages are completed, the development of teaching materials will be seen whether it is feasible and practical to use. The following is a schematic description of the flowchart of developing teaching materials for elementary mathematics basic concepts with the internalization of Islamic values.

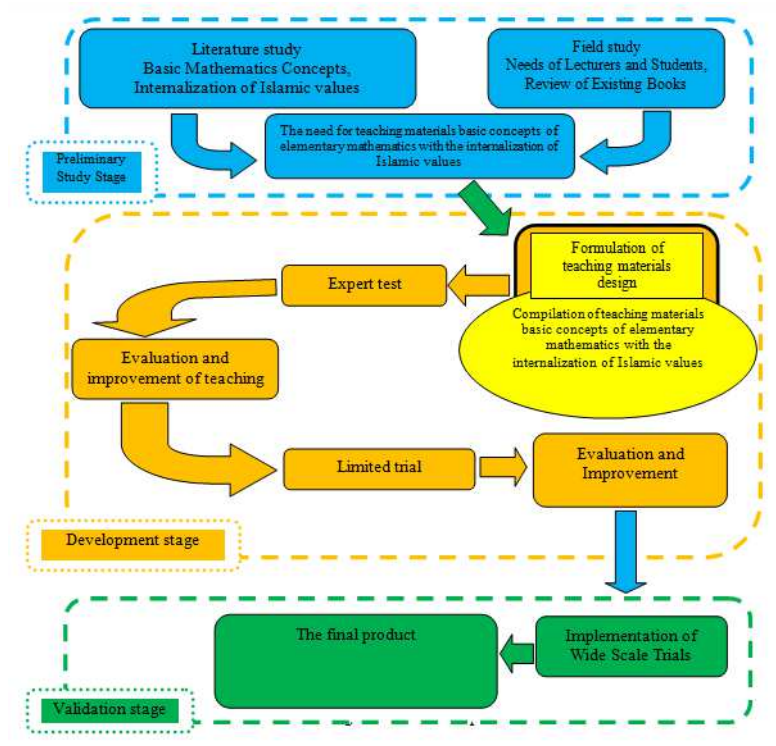

Fig. 1. The flow of teaching materials development

From Figure 1 above, it can be seen that the stages of research on the development of teaching materials are carried out by a process that is not short. As for the stages of the validation test of teaching materials, there are stages: 1) Validation of teaching material products, teaching materials are validated by a validator (Expert / Expert). When validating, the validator provides suggestions and comments regarding the aspects and criteria of teaching materials directly on the teaching material validation sheet. 2) Limited trial (small group), the implementation of the limited trial plan is carried out by involving 5 students. 3) Broad-scale trials, the results of limited trials are evaluated and revised teaching materials as needed, then extensive trials are carried out on all students. This trial design is used to test the teaching materials developed in the form of elementary mathematics basic concepts teaching materials with the internalization of Islamic values. The instruments used in this study were 1) interview guide, used to interview lecturers and students. This interview was conducted to find out preliminary data related to potential and problems that occur at school. 2) A questionnaire 
sheet, consisting of a validation questionnaire for teaching materials, which is used to determine the validity of teaching materials for elementary mathematics basic concepts by internalizing Islamic values through expert validators. And the student and lecturer response questionnaire sheets are used to determine student responses and lecturer responses after the implementation of learning using elementary mathematics basic concepts teaching materials with internalization of Islamic values.

The data analysis used is related to the analysis on the expert validation sheet and analysis of practicality. The validator will provide the results of an assessment of the teaching materials according to the rubric. The validation sheet contains the assessment data of each validator of the teaching materials analyzed based on the average score. The average score of each validator is calculated by means of the average score equal to the number of validator scores in each aspect divided by the number of aspects of the assessment, with the criteria that the learning device is said to be valid if the average score of each device is in the good or excellent category. The following are the criteria for expert validation.

Table 1. Criteria for average validation test scores

\begin{tabular}{lll}
\hline No & Average score & Criteria \\
\hline 1 & $1,0 \leq$ average $<1,8$ & Not Good \\
2 & $1,8 \leq$ average $<2,6$ & Less \\
3 & $2,6 \leq$ average $<3,4$ & Enough \\
4 & $3,4 \leq$ average $<4,2$ & Good \\
5 & $4,2 \leq$ average $\leq 5,0$ & Very good \\
\hline
\end{tabular}

In the practicality analysis, it was obtained from the questionnaire sheet data for the lecturers' ability level when managing learning using the developed teaching materials. Data analysis on the ability to manage learning is analyzed by calculating the average value of each aspect of managing learning. The ability to manage learning is said to be good if every aspect assessed is at least good. The criteria used are the same as the validation test criteria. In addition, the practicality test is also calculated from the analysis of student responses to the teaching materials developed. Analysis of student response questionnaire data is based on the average student choice on the questionnaire sheet, with each statement given a choice of scores of 1,2,3,4 or 5. The device is said to be practical if the ability to manage learning is in the good or very good category and the student's response is at good or very good category. 


\section{Results and Discussion}

The stage of developing teaching materials in accordance with the development method that has been presented consists of 3 stages, namely the preliminary study stage, the development stage and the validation stage. This development stage has also been carried out by Jubaedah, Y., Rohaeni, N., Rinekasari, N. R., \& Rohmah, I. (2018)[11]. In the preliminary study stage, field studies and literature studies have been carried out. Field studies were carried out in elementary mathematics basic concepts lectures using interview instruments to lecturers. The results of the field study were reviewed and linked to supporting literature. The results of the field study were obtained 1) the teaching materials used did not contain the internalization of Islamic values, 2) required teaching materials with the integration of Islamic values, 3) students needed material guidelines for basic concepts with the integration of Islamic values, 4) had not the availability of teaching materials makes student learning outcomes not optimal, 5) teaching materials developed are expected to improve the cognitive, affective and psychomotor domains. Based on the results of the field study, researchers used material to solve it with literature studies. The most important literature in this case is the Al quran. And of course supported by other sources related to material mathematical concepts and Islamic values.

At the development stage there is a validation test. Teaching materials developed must meet valid criteria. The validation test is carried out on 2 aspects, namely validation of material shli and validation of linguists. The validators selected were 3 lecturers, namely lecturers who taught elementary mathematics basic concepts, Indonesian language lecturers, and Islamic education lecturers. From the three validators, a recapitulation of the validity test results is obtained as in Table 2 below.

Table 2. Recapitulation of Material Expert Validation

\begin{tabular}{|c|c|c|c|c|}
\hline \multirow[t]{2}{*}{ No } & \multirow[t]{2}{*}{ Aspects Assessed } & \multicolumn{3}{|c|}{ Validator } \\
\hline & & V1 & V2 & V3 \\
\hline A & Cover Page & & & \\
\hline 1 & Cover page according to the content of the material & 4 & 3 & 3 \\
\hline 2 & $\begin{array}{l}\text { The description on the cover page matches the } \\
\text { content of the material }\end{array}$ & 3 & 4 & 4 \\
\hline B & Foreword & & & \\
\hline 3 & The author's hope is to represent the entire book & 4 & 3 & 4 \\
\hline 4 & $\begin{array}{l}\text { The books developed are in accordance with the } \\
\text { basic concepts of mathematics }\end{array}$ & 4 & 4 & 4 \\
\hline $\mathrm{C}$ & $\begin{array}{l}\text { Table Of Contents And Instructions For Use Of } \\
\text { The Book }\end{array}$ & & & \\
\hline 5 & $\begin{array}{l}\text { The suitability of the preparation of the table of } \\
\text { contents }\end{array}$ & 4 & 3 & 5 \\
\hline 6 & $\begin{array}{l}\text { Linkage of table of contents to manuals for book } \\
\text { use }\end{array}$ & 3 & 4 & 3 \\
\hline 7 & $\begin{array}{l}\text { Compliance of instructions with material } \\
\text { performance }\end{array}$ & 4 & 4 & 3 \\
\hline $\mathrm{D}$ & Book Contents & & & \\
\hline 1 & There are material achievements & 5 & 4 & 5 \\
\hline 2 & There are practice questions & 5 & 4 & 3 \\
\hline 3 & Linkage of material with material outcomes & 4 & 4 & 3 \\
\hline 4 & The material provided is structured and clear & 4 & 4 & 4 \\
\hline 5 & Contains internalization of Islamic values & 4 & 4 & 3 \\
\hline
\end{tabular}



each material

7 Relation of material with the verses of the Qur'an conveyed

8 Writing the formula clearly and correctly

6 The content of teaching materials is presented attractively

7 The material packaged in teaching materials can be used as reference material

8 Layout and content design of teaching materials $\quad \begin{array}{llll}5 & 5 & 4\end{array}$

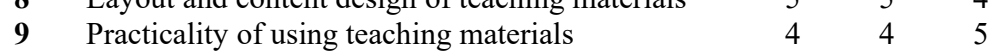

10 There is an internalization of Islamic values that $\quad \begin{array}{lll}4 & 4 & 4\end{array}$ are presented in addition to the Koran such as hadiths, stories of friends, etc.

\begin{tabular}{cccc}
\hline Total & 79 & 76 & 77 \\
\hline Average score of each validator & 3.95 & 3.80 & 3.85 \\
\hline Average score & \multicolumn{3}{c}{3.87} \\
\hline Criteria & \multicolumn{3}{c}{ Good } \\
\hline
\end{tabular}

From the results of the material expert validation test obtained an average score of 3.87 with good criteria. Thus the teaching materials have met the criteria for use. Seen in the table above, the material available is teaching material in accordance with the material achievements and has been related to the internalization of Islamic values. Each chapter has included a verse from the Qur'an and there is also a moral message in it. The cover design and materials are well presented and dance. If the average of each aspect is calculated, the data is obtained as the graph in Figure 2 below.

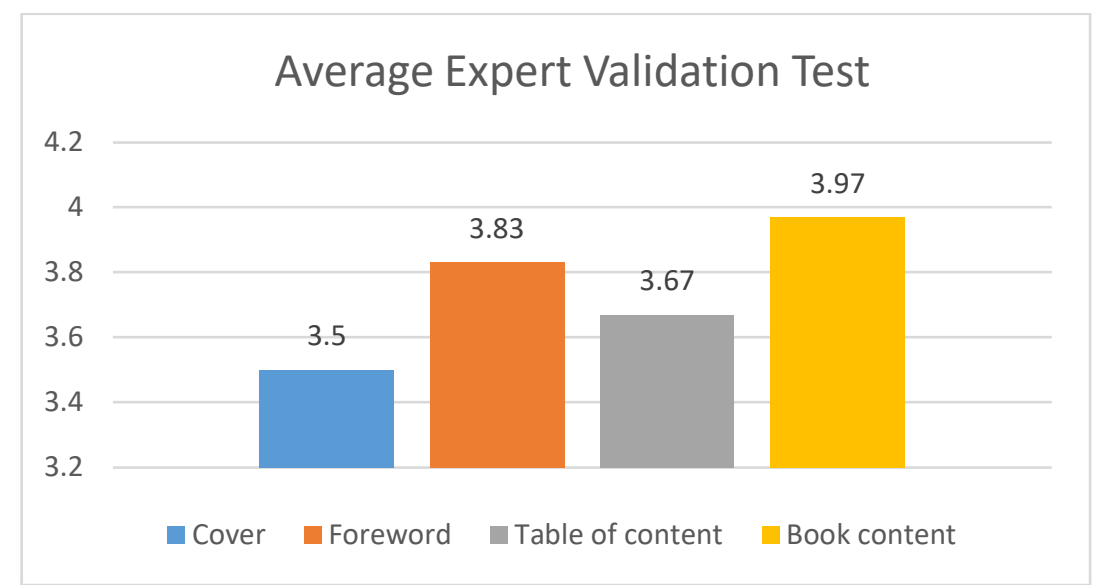

Fig. 2. Graph of the average score of the material expert validation aspect

In addition to validating material experts, linguist validation is also carried out. Teaching materials are assessed based on linguistic aspects. This validation test was also carried out by 3 validators from the lecturers. The following is table 3 of the aspects assessed in the linguist validation test.

Table 3. Linguist validation test aspects

\begin{tabular}{llccc}
\hline No & Aspects Assessed & \multicolumn{3}{c}{ Validator } \\
\cline { 3 - 4 } & & V1 & V2 & V3 \\
\hline
\end{tabular}




\begin{tabular}{|c|c|c|c|c|}
\hline \multirow[t]{2}{*}{ No } & \multirow[t]{2}{*}{ Aspects Assessed } & \multicolumn{3}{|c|}{ Validator } \\
\hline & & V1 & V2 & V3 \\
\hline 1 & $\begin{array}{l}\text { The writing on the cover is in accordance with } \\
\text { the EYD }\end{array}$ & 5 & 4 & 5 \\
\hline 2 & $\begin{array}{l}\text { The descriptions on the front and back cover } \\
\text { pages are easy to understand }\end{array}$ & 4 & 3 & 4 \\
\hline 3 & The suitability of writing with the material & 4 & 4 & 4 \\
\hline 4 & $\begin{array}{l}\text { The suitability of Arabic writing (Al-Qur'an) in } \\
\text { teaching materials }\end{array}$ & 4 & 4 & 4 \\
\hline 5 & $\begin{array}{l}\text { The book that was developed is in accordance } \\
\text { with the basic concepts of mathematics }\end{array}$ & 4 & 3 & 4 \\
\hline 6 & $\begin{array}{l}\text { The language used is in accordance with the } \\
\text { EYD }\end{array}$ & 3 & 4 & 3 \\
\hline 7 & The language used is formal & 5 & 4 & 4 \\
\hline 8 & The sentences used are effective & 4 & 3 & 5 \\
\hline 9 & Does not cause multiple interpretations & 3 & 4 & 4 \\
\hline 10 & The language used is easy to understand & 4 & 3 & 3 \\
\hline & Total & 40 & 36 & 40 \\
\hline & Average score of each validator & 4.00 & 3.60 & 4.00 \\
\hline & Average score & & 3.87 & \\
\hline & Criteria & & Good & \\
\hline
\end{tabular}


From the recapitulation of the results of the linguist validation test, it was obtained an average score of 3.87 with good criteria. So that the teaching materials have met the criteria for use. From the results of the recapitulation, it can be concluded that the basic concepts of elementary mathematics teaching materials with the internalization of Islamic values have met the applicable spelling, the language used is easy to understand, formal, effective and unambiguous. The writing of the Alquran contained in it is correct, there are no typographical errors. If the average score is calculated for each aspect of the assessment, it is obtained as the graph in Figure 3 below.

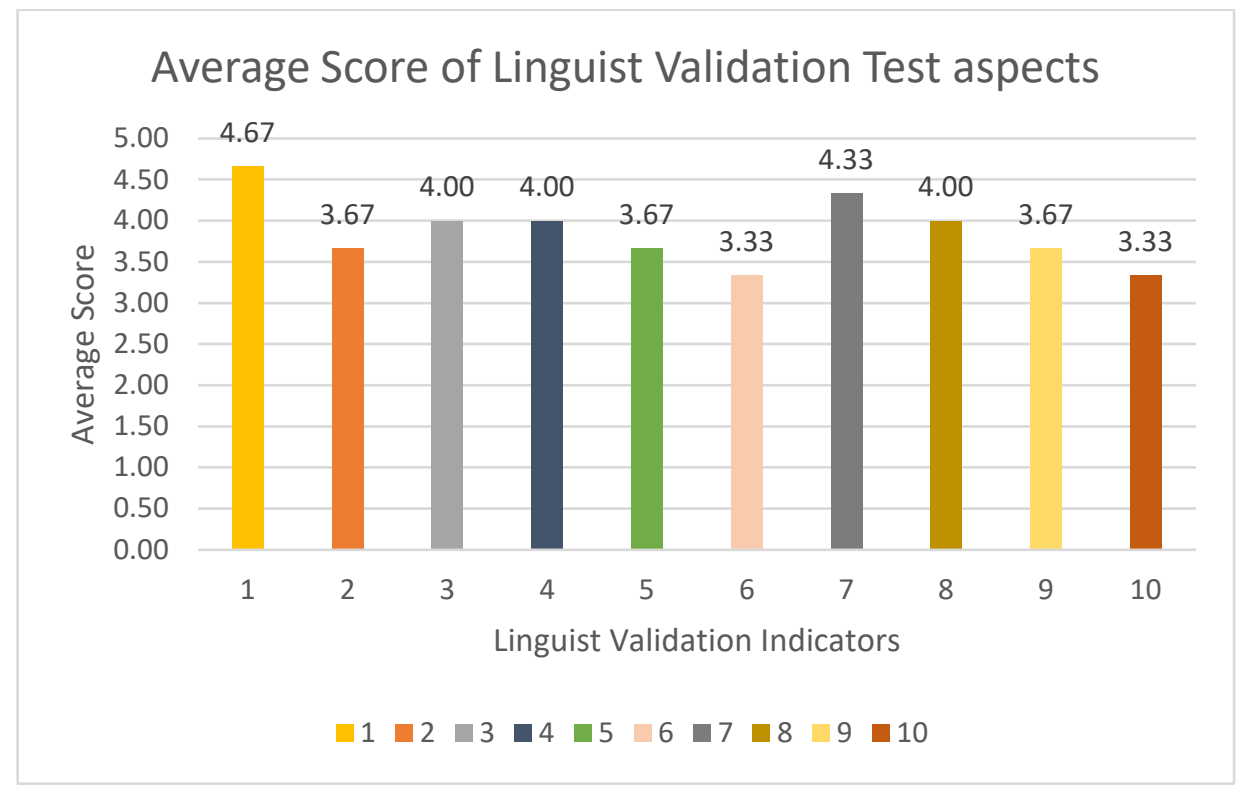

Fig. 3. Graph of the average score of linguist validation aspects

Based on the acquisition of material expert and linguist validation test scores that meet the valid criteria, it can be concluded that the teaching material is suitable for use. Apart from being obtained from the validation sheet questionnaire data, the validator also provided input on the teaching materials being developed. The suggestions from the validator include the following.

a) In the format of the numbering system, pay more attention, there are some inconsistencies, for example still containing bullets. Better all in the form of consistent numbering for each chapter.

b) The indicators listed must be related to learning outcomes. some indicators need to be reviewed and reassessed.

c) The type and size of the font is adjusted to the age of the reader. Because this teaching material is lecture teaching material, the font size is quite standard.

d) For the layout or layout is good. It's just that the image used if the download is the source, it is necessary to include the source. Or better if the original image from the compiler itself. 
e) The grammar used is good and appropriate for the age of the reader. However, for clarity of instructions, there are still some pointers that need to be corrected because they contain multiple or ambiguous meanings.

f) Regarding the content of teaching materials, suggestions and there are many comments and corrections related to Al-Qur'an verses related to mathematical concepts. Islamic values related to the basic concepts of mathematics.

These suggestions become material for evaluation and improvement, the teaching materials have been revised according to the suggestions given. Thus the teaching material is valid, which means that the teaching material can measure what should be measured [12]. At the development stage there is also a limited scale test which is carried out in elementary mathematics basic concepts lectures involving 4 students. The finite scale test is used to measure practicality. Practical means that the instrument is easy to use [13] . The limited trial was conducted with 4 students participating in elementary mathematics basic concepts courses. The instrument used was a student response questionnaire related to learning using the teaching materials developed. The results of the student response questionnaire instrument on this limited test obtained an average score of 4.63 on excellent criteria. The results of this analysis show that the teaching materials can be used in large-scale trials.

In the next stage, namely the validation stage, the researcher applies the teaching materials developed to large groups. From the results of large group trials, it was found that an average score of 4.51 was included in the very good criteria. From the three stages of development that have been carried out, it can be concluded that the teaching materials for elementary mathematics basic concepts with the internalization of Islamic values have met the valid and practical criteria. So that it is fulfilled if it is applied and used to measure other variables. The teaching material developed includes the integration of Islamic values in the basic concepts of mathematics, especially in elementary schools. Each chapter in the teaching material is given a verse from the Koran that is in accordance with the application of moral values. Thus, teaching materials can be used as a reference in lectures. Because with the development of teaching materials, it can be used as the best reference and reference material in implementing learning [12] . As an example in the material of sequences and series. The related verse of the Qur'an is the chapter $\mathrm{Al} \mathrm{Kahf} \mathrm{verse} 22$ which reads:

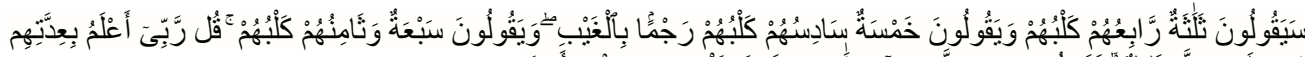

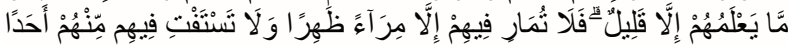

Which means : "22. later (some will) say [878] (their number) is three people of which the fourth is the dog, and (another) says: "(their number) is five of the sixth is the dog", as a conjecture of the goods magical; and (yet another) said: "(their number) was seven, the eighth was the dog." Say: "My Lord knows their number better; no one knows (their number) except a few". therefore do not you (Muhammad) quarrel about their things, except only birth fights and do not ask about them (the youths) to any of them."

If we read and try to understand the translation then we can imagine that someone is trying to guess the number of Ashabul Kahf (The young men and their dogs) while the exact number they know is $1 \mathrm{dog}$, while the number of young people is still a question mark. If we associate it with mathematics, we can make the notation as follows.

$U n=n+1$ 
where $n$ is the number of young men who are still question mark, and 1 is their dog.

$U 3=3+1=4$

As it is stated in the verse, if there are 3 of them then the 4th is the dog.

$U 5=5+1=6$

As it is stated in the verse, if there are 5 of them then the 6th is the dog.

$U 7=7+1=8$

As it is stated in the verse, if there are 7 of them then the 8 is the dog.

From the explanation above, it turns out that if you pay more attention, you will see a pattern of sequences and artistic series that are formed. So for centuries before Johann Carl Friedrich discovered the arithmetic series formula, this formula was already written in the Koran. The moral values that can be conveyed are consistency and responsibility. From the rows and rows, a pattern will be obtained with predetermined rules and regulations. If it does not follow the rules or pattern of the sequence, then of course it is not part of the sequence and sequence. In other words, the message conveyed is that we have to follow the rules if we are part or members of a group. For example, as Indonesian citizens, we must obey the rules of the Indonesian state. If not, then we will automatically leave Indonesia. Another example is the material on number systems and number operations. In the Al quran there are many verses that mention numbers and numbers. This means that the number has long been introduced by Islam. Here are some examples of verses from the Quran that contain numbers.

Paragraph 1 Q.S. Al-Ikhlas

Meaning: "Say (Muhammad)," He is Alla, the One and Only. "

Verse 4 Q.S. Yusuf

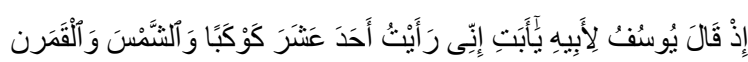

Meaning: "(remember) when Yusuf said to his father," O my father! indeed, I (dreamed) saw eleven stars, the sun and the moon; I saw everything bowed down to me."

Verse 147 Q.S. As-Shaffat

Meaning: "And we sent him to a hundred thousand (people) or more."

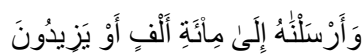

Verse 261 Q.S. Al-Baqarah

مثل ألذين ينفقون أمو لهم فى سبيل ألله كمثل حبة أنبتت سبع سنابل فى كل سنبلة مائة حصبة و ألله يضعف لمن يثآه و ألله وسع

This means: "The parable of a person who spends his wealth in the way of Allah is like a seed that grows seven stalks, on each stalk there are a hundred seeds. Allah multiplies for whom $\mathrm{He}$ wills, and Allah is Vast, All-Knowing. "

Verse 11 Q.S. Annisa‘ 


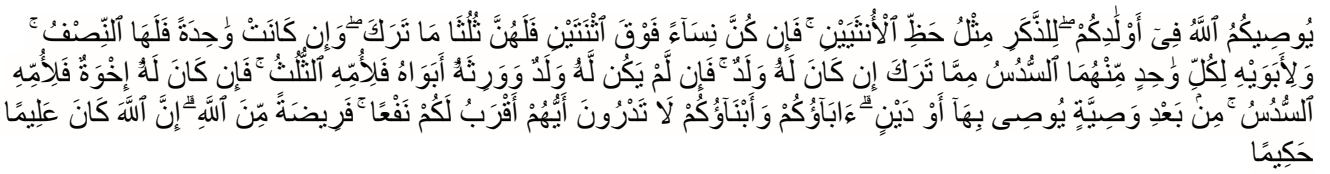

This means: "Allah requires (requires) you about (the distribution of inheritance for) your children, (that is) the portion for a boy is the same as that for two daughters. And if the children are all more than two women, then their share is two-thirds of the property left behind. If she (daughter) is alone, then she gets half (the property left behind). And for both mother and father, each share one-sixth of the property left, if he (who died had children). If he (who dies) does not have children and he is inherited by his mother-father (only), then the mother gets one third. If he (who died) had several siblings, that is why his mother got one sixth. (The distribution mentioned above) after (fulfilled) the will made or (and after being paid) the debt. (Concerning) your parents and your children, you do not know which of them is more beneficial to you. This is a decree of Allah. Truly, Allah is All Knowing, All Wise. "

The above verses are a small sample of the numbers mentioned in the Quran. In the above verse, numbers ranging from units, tens, hundreds, and fractions are conveyed. Apart from that, it is also discussed with regard to operations both addition, subtraction, multiplication and even division. The moral value depends on the verse conveyed, because each verse even though it contains the same number, the context is different. It is hoped that the developed teaching materials can make students have strong faith, behavior that has commendable character as similar research conducted by Hanif et al [14] in the field of science. The integration of religion and science into a new scientific paradigm of educational models will be able to deliver graduates to have more complete knowledge, personality, and insight who have the ability of IMTAQ (faith and piety) as well as science and technology (science and technology). A supportive learning atmosphere is needed in learning [15]. Therefore, in learning an Islamic atmosphere is formed, namely learning with teaching materials based on the internalization of Islamic values.

\section{Conclusion}

Based on the results of research and discussion, it can be concluded as follows.

a) The developed teaching material contains the link between the Qur'anic verses and the material of mathematical concepts along with the relevant moral messages. The stage of developing teaching materials for basic concepts of elementary mathematics with internalization of Islamic values includes 1) preliminary study, 2) development stage and 3) validation stage.

b) The results of the validation of elementary school mathematics basic concepts teaching materials with the internalization of Islamic values obtained an average score of 3.87 with good criteria, while the results of the practicality test obtained an average score of 4.36 on the very good criteria in limited trials. and in large-scale trials an average of 4.51 was obtained on very good criteria. 


\section{Refference}

[1] Ulia, N., \& Sari, Y. (2018). Pembelajaran Visual, Auditory dan Kinestetik Terhadap Keaktifan dan Pemahaman Konsep Matematika Siswa Sekolah Dasar. Al Ibtida: Jurnal Pendidikan Guru MI, 5(2), 175-190.

[2] Kemenristekdikti. 2016. Panduan Program Insentif Bahan Ajar dan Pedoman Pembelajaran. Kemenristekdikti:Jakarta

[3] Depdiknas. 2008. Paduan Pengembangan Bahan Ajar, (Online), (http://www.docs/2879709/5 Paduan-Pengembangan-Bahan-Ajar.html diakses 28 Mei 2018)

[4] Abdussakir. 2017. Internalisasi Nilai-Nilai Islami dalam Pembelajaran Matematika dengan Strategi Analogi. Disajikan pada Seminar Nasional Integrasi Matematika dan Nilai Islami (SiManis) 2017, 6 Mei 2017, Jurusan Matematika FST UIN Maulana Malik Ibrahin Malang.

[5] Abdussakir. 2005. Matematika dan Al Qur'an. Disajikan pada Seminar Integrasi Matematika, Al Qur'an dan Kehidupan Sosial, 3 Agustus 2005, Topografi Komando Daerah Militer V Brawijaya, Malang.

[6] Kohar, A.W. 2010. Membumikan Pendidikan Nilai Melalui Integrasi Nilai Islam dalam Pembelajaran Matematika. Makalah Seminar Pendidikan Matematika. (Online) https://bangqohar.wordpress.com/2012/10/16/membumikan pendidikan-nilai-melaluiintegrasinilai-islam-dalam-pembelajaranmatematika.

[7] Kurniati, A. 2015. Mengenalkan Matematika Terintegrasi Islam Kepada Anak Sejak Dini. Suska Journal of Mathematics Education. 1(1):1-8

[8] La Jamaa. (2015). Integrasi Matematika dan Islam. (Online) https://syariah.iainambon.ac.id/index.php/artikel-dosen/integrasimatematika-dan-islamdr-la-jamaamhi.

[9] Nihayati. 2017. Integrasi Nilai-nilai Islam dengan materi Himpunan (kajian terhadap Ayat-Ayat Al Qur'an). Jurnal Edumath. 3(1):65-77

[10] Samsudi.2006. Desain Penelitian Pendidikan. Semarang: Unnes Press

[11] Jubaedah, Y., Rohaeni, N., Rinekasari, N. R., \& Rohmah, I. (2018). Model Competency Based Assessment Pada Pengembangan Job Performance Public Area Di Housekeeping Department. Jurnal Kesejahteraan Keluarga dan Pendidikan, 5(2), 139146.

[12] Ulia, N., Sari, Y., Yustiana, S., \& Hariyono, M. (2020). The influence of mathematical basic concept of materials based on internalization of Islamic values against religious attitude. In Journal of Physics: Conference Series (Vol. 1517, p. 012060).

[13] Yustiana, S., \& Ulia, N. (2019). Pengembangan Instrumen Penilaian Diri Berbasis Pembelajaran Kontekstual. Profesi Pendidikan Dasar, 1(2), 179-188.

[14] Hanif, H., Ibrohim, I., \& Rohman, F. (2016). Pengembangan Perangkat Pembelajaran Biologi Materi Plantae Berbasis Inkuiri Terbimbing Terintegrasi Nilai Islam Untuk Meningkatkan Pemahaman Konsep Siswa Sma. Jurnal Pendidikan: Teori, Penelitian, dan Pengembangan, 1(11), 2163-2171.

[15] Ulia, N. (2018). Efektivitas Colaborative Learning Berbantuan Media Short Card Berbasis IT Terhadap Pemahaman Konsep Matematika. Jurnal Ilmiah Pendidikan Dasar, 3(2), 1-11. 